\title{
Different mutations of the human c-mpl gene indicate distinct haematopoietic diseases
}

\author{
Xin $\mathrm{He}^{1 \dagger}$, Zhigang Chen ${ }^{2 \dagger}$, Yangyan Jiang ${ }^{3}$, Xi Qiu ${ }^{1}$ and Xiaoying Zhao ${ }^{1 *}$
}

\begin{abstract}
The human c-mpl gene (MPL) plays an important role in the development of megakaryocytes and platelets as well as the self-renewal of haematopoietic stem cells. However, numerous MPL mutations have been identified in haematopoietic diseases. These mutations alter the normal regulatory mechanisms and lead to autonomous activation or signalling deficiencies. In this review, we summarise 59 different MPL mutations and classify these mutations into four different groups according to the associated diseases and mutation rates. Using this classification, we clearly distinguish four diverse types of MPL mutations and obtain a deep understand of their clinical significance. This will prove to be useful for both disease diagnosis and the design of individual therapy regimens based on the type of MPL mutations.
\end{abstract}

Keywords: MPL, Mutations, Mechanism, Individual therapy, Haematopoietic diseases

\section{Introduction}

The human c-mpl gene (MPL), a cellular homologue of the oncogene v-mpl, belongs to the haematopoietic receptor superfamily $[1,2]$. The protein encoded by $M P L$, $\mathrm{CD} 110$, is a 635-amino acid protein consisting of four functional domains: the putative signal peptide, the extracellular domain, the transmembrane domain and the intracellular domain. These domains correspond to exon 1 , exons 2-9, exon 10 and exons 11-12, respectively [3].

In the absence of the CD110 ligand, thrombopoietin (TPO), the extracellular domain, transmembrane domain and an amphipathic motif, KWQFP, localised at the transmembrane-cytoplasmic junction, retain CD110 in the inactive state [4-6]. When TPO binds to CD110, CD110 is dimerised and the tyrosine kinases JAK2 and TYK2 become activated, which in turn triggers the activation of downstream positive signalling pathways, including JAK-STAT/Crkl, SHP2-Bad, SHC-MAPK, and PLC-PKC [7-19]. It has been suggested that CD110 and TPO play an important role in the development of megakaryocytes and platelets as well as the self-renewal of haematopoietic stem cells $[3,20,21]$.

\footnotetext{
*Correspondence: zrxzzz@126.com

${ }^{\dagger}$ Equal contributors

'Department of Hematology, the Second Affiliated Hospital, Zhejiang

University School of Medicine, Hangzhou 310009, China

Full list of author information is available at the end of the article
}

However, various MPL mutations alter the normal regulatory mechanisms; some may cause a complete or partial loss of CD110 function, thus leading to thrombocytopenia, while other types of mutations result in the autonomous activation of CD110 and the development of thrombocytosis (Summarised in Figure 1).

\section{Several MPL mutations have been identified in association with haematopoietic diseases}

Since the first two heterozygous MPL point mutations were identified in congenital amegakaryocytic thrombocytopenia (CAMT) in 1999, mutations in hereditary thrombocythaemia (HT), myeloproliferative neoplasms (MPNs), refractory anaemia with ringed sideroblasts associated with marked thrombocytosis (RARS-t) and acute myeloid leukaemia (AML) have been identified [22]. CAMT is a rare inherited disorder that presents with thrombocytopenia at birth, which eventually progresses into pancytopenia without physical malformations. MPL mutations associated with this disease are autosomal, recessive germline mutations, which play a decisive role in the course of the disease [23,24]. According to the data collected by Ballmaier et al., we calculated the mutation rate of the MPL gene to reach as high as $91.8 \%$ (56 out of 61 CAMT patients for whom $M P L$ sequencing revealed $M P L$ mutations); no mutations other than those found in the $M P L$ 


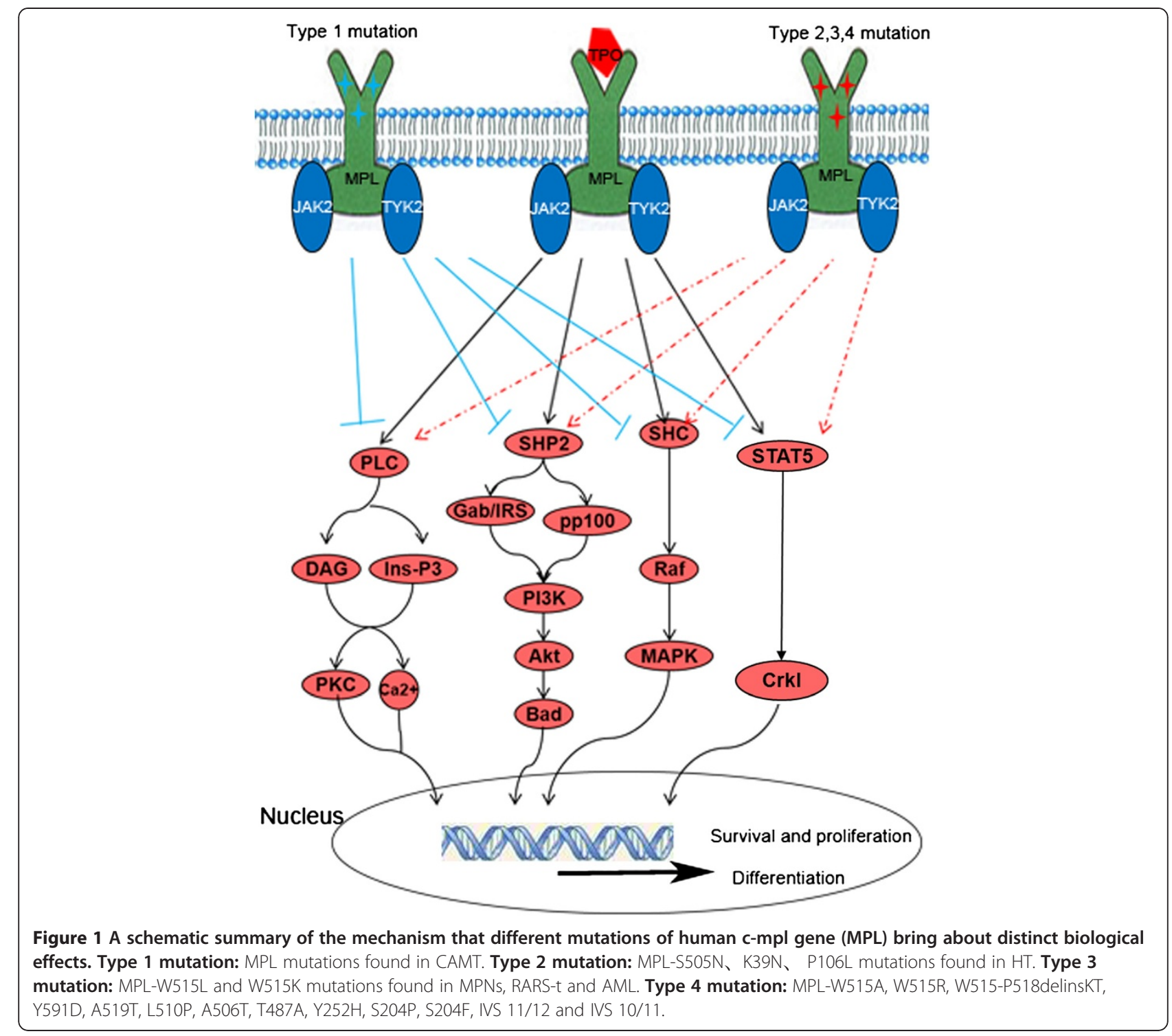

gene have been identified in CAMT patients [25]. HT, a hereditary disease of thrombocythaemia, is the second disease that was shown to be associated with MPL mutations. The MPL mutations detected in HT patients, S505N, K39N and P106L, are also germline mutations. These mutations are inherited in a number of ways: autosomal dominant inheritance, autosomal dominant inheritance with incomplete penetrance and autosomal recessive inheritance with possible mild heterozygote manifestation, respectively. Various somatic mutations, such as MPL-W515L, W515K, W515A, W515R, and W515-P518delinsKT, have also been detected in MPN samples, such as polycythaemia vera (PV), primary myelofibrosis (PMF) and essential thrombocythaemia (ET), which manifest as the overproduction of one or more myeloid lineages.

\section{Classification of MPL mutations}

We reviewed relevant papers published from 1999 to 2012 and found that 59 different MPL mutations have been reported. According to the frequency of $M P L$ mutations and the associated clinical conditions, such as inheritance pattern, diagnosis, clinical manifestation and laboratory results, we categorised these mutations into four different groups as follows (summarised in Table 1):

Type1. MPL mutations found in CAMT;

Type 2. MPL - S505N, K39N and P106L mutations found in HT;

Type 3. MPL - W515L and W515K mutations found in MPNs, RARS-t and AML;

Type 4. Other MPL mutations: MPL-W515A, W515R, W515-P518delinsKT, Y591D, A519T, L510P, A506T, 
Table 1 Classfication and clinical features of MPL mutations indentified in hematopoietic diseases

\begin{tabular}{|c|c|c|c|c|c|}
\hline Mutation type & Mutation and Inheritance pattern & Effect & $\begin{array}{l}\text { clinical } \\
\text { manifestation }\end{array}$ & Disease (mutation rate) & Reference \\
\hline $\begin{array}{l}\text { Type } 141 \\
\text { different MPL } \\
\text { mutations in } \\
\text { CAMT }\end{array}$ & Autosomal recessive Germline mutation & $\begin{array}{l}\text { Completely lose } \\
\text { or significantly } \\
\text { reduce MPL } \\
\text { function }\end{array}$ & Thrombocytopenia & CAMT (about 91.8\%) & $(25-30)$ \\
\hline Type 2 S505N & $\begin{array}{l}\text { Autosomal dominant Germline mutation, } \\
\text { rare somatic mutation }\end{array}$ & $\begin{array}{l}\text { Autonomous } \\
\text { activate MPL } \\
\text { function }\end{array}$ & Thrombocytosis & $\mathrm{HT}$ (about 54.5\%) & $(22,24,34,35)$ \\
\hline K39N,P106L & $\begin{array}{l}\text { Autosomal dominant with incomplete } \\
\text { penetrance and autosomal recessive with } \\
\text { possible mild heterozygote manifestation } \\
\text { germline mutation }\end{array}$ & $\begin{array}{l}\text { Reduce binding } \\
\text { affinity to } \\
\text { ligand } \\
\text { thrombopoietin }\end{array}$ & Thrombocytosis & $\begin{array}{l}\text { HT (7\% of African-American } \\
\text { individuals and } 6 \% \text { of Arab } \\
\text { individuals) }\end{array}$ & $(40,41)$ \\
\hline Type 3 W515L/K & Somatic mutation & $\begin{array}{l}\text { Autonomous } \\
\text { activate MPL } \\
\text { function }\end{array}$ & Thrombocytosis & $\begin{array}{l}\text { MPNs (about } 1 \% \text { in ET and } 5 \% \\
\text { in PMF, rare in PV), AMKL } \\
\text { with myelofibrosis (about } \\
25 \% \text { ),rare in RARS-t }\end{array}$ & $\begin{array}{l}(48-50,57,59 \\
66-69)\end{array}$ \\
\hline $\begin{array}{l}\text { Type } 4 \text { W515A/R, } \\
\text { T487A,Y252H }\end{array}$ & Somatic mutation & $\begin{array}{l}\text { Autonomous } \\
\text { activate MPL } \\
\text { function }\end{array}$ & Thrombocytosis & $\begin{array}{l}\text { Rare in MPNs囚 AMKL and ET } \\
\text { respectively }\end{array}$ & $(52,57,59,70,71)$ \\
\hline $\begin{array}{l}\text { A519T,L510P and } \\
\text { A506T }\end{array}$ & Somatic mutation & $\begin{array}{l}\text { No function or } \\
\text { maybe regulate } \\
\text { other genetic } \\
\text { events. }\end{array}$ & Unknown & Rare in PMF & $(57)$ \\
\hline $\begin{array}{l}\text { W515- } \\
\text { P518delinsKT, } \\
\text { Y591D,S204P/F, } \\
\text { IVS 11/12 and IVS } \\
\text { 10/11 }\end{array}$ & Somatic mutation & Unclear & Unknown & Rare in MPNs & $(72-74)$ \\
\hline
\end{tabular}

T487A, Y252H, S204P, S204F, IVS 11/12 and IVS 10/11.

\section{MPL mutations found in CAMT}

Currently, 41 different $M P L$ mutations have been detected in CAMT samples [25]. They can be classified into nonsense mutations, deletions and frameshift mutations, missense mutations and splice site mutations. Ballmaier et al. analysed 9 patients with CAMT and found that the types of MPL mutations correlated with the clinical course of the disease [26]. King then proposed a new classification of CAMT, type I and type II, based on the course of the disease and the types of MPL mutations [27].

CAMT type I is characterised by persistently low platelet counts and early progression to bone marrow failure. Nonsense, deletions and frameshift MPL mutations, such as $M P L$ c.127C $>\mathrm{T}$ and c.378delT, may be responsible for this disease type, as these mutations introduce premature stop codons and thus cause a complete loss of CD110 function [28]. In in vitro assays, CD110 is not expressed in K562 cells with nonsense mutations; therefore, no TPO-driven signalling can be detected [29]. Colony assays have also revealed that the total number of colony forming cells derived from CAMT I patients with nonsense mutations was significantly reduced compared with normal donors [28].
CAMT II displays a less aggressive course with a transient increase in platelet counts during the first year and delayed or no progression of pancytopenia. Additionally, types of missense and splice site $M P L$ mutations, such as the most frequent mutation, c.305G $>\mathrm{C}$, are closely associated with CAMT II. This is because these mutations cause amino acid changes or mRNA splicing defects in CD110, which do not completely abrogate the function of CD110 but leave residual activity [28-30]. Two lines of evidence support this hypothesis: 1. TPO-driven signalling is significantly reduced but not eliminated in K562 cells with missense mutations in in vitro assays [29] and 2. Colonyforming cells derived from CAMT II patients with missense mutations remain reactive to TPO [28].

In general, several studies have confirmed the genotypephenotype correlation in CAMT [28,31,32]. However, as few reports discuss the relationship between MPL mutations and brain abnormalities, malignant transformation in CAMT is still unclear $[23,32,33]$. Due to the causative function of MPL mutations, especially nonsense mutations, in CAMT, gene therapy aimed to correct CD110 deficiency seems possible.

MPL-S505N, K39N, and P106L mutations associated with HT $M P L-S 505 \mathrm{~N}$ is an activating mutation that was first detected by Ding et al. in all members of a specific Japanese 
family with HT [22]. They found that the Ba/F3 cells transfected with the mutant type (S505N) but not the wild type DNA survived, even without growth factor stimulation [22]. Additionally, a study has demonstrated the constitutive activation of downstream signals without factor dependence in both $\mathrm{Ba} / \mathrm{F} 3$ cells with the $\mathrm{S} 505 \mathrm{~N}$ mutation and platelets of the $5505 \mathrm{~N}$ mutant derived from HT patients [22]. How does MPL-S505N induce ligand-independent phosphorylation of downstream signalling molecules? At least two mechanisms have been elucidated: 1. MPL-S505N transduces the signal via the autonomous dimerisation of the MPL protein due to strong amino acid polarity [34] and 2. MPL-S505N leads to movement of the transmembrane domain and conformational changes, including tilt and azimuthal rotational angles along the membrane axis, which alter the conformation of the nearby intracellular domain and thus induce constitutive signal activation [35].

To elucidate the biologic profile of MPNs, Teofili et al. have assessed 38 children with PV and ET [36]. However, when they conducted the MPL gene mutation analysis, they identified MPL-S505N in 9 of 11 children with ET, thereby suggesting that these paediatric cases of familial ET are in fact HT, which led them to question the revised WHO diagnostic criteria for ET. To evaluate this observation, they increased the number of children in the study and still found erroneous diagnoses for children with ET [37]. Therefore, they proposed that to avoid erroneous diagnoses, the first step of the diagnostic screening should be to test for MPL-S505N in those children with thrombocythaemia who had a familial history [38]. Recently, the same group extended their study to include 44 HT patients, including both children and adults, and found that 22 of the 44 patients (approximately $54.5 \%$ ) carried the $M P L-S 505 \mathrm{~N}$ mutation. At the median follow-up of 9 years for the 22 patients with this mutation, they observed thrombotic manifestation in 4 cases, myocardial infarction in 7 cases, foetal loss in 2 cases, deep vein thrombosis of the leg and Budd Chiari syndrome in 2 cases, and splenomegaly and bone marrow fibrosis in almost all patients. Therefore, they concluded that MPL-S505N was associated with clinical manifestations such as a significant thrombotic risk, which, with age, evolved to splenomegaly and bone marrow fibrosis, thereby noticeably affecting patient life expectancy [24]. Interestingly, most of the HT cases reported with MPL-S505N were from Italian families; Liu et al. have also observed this phenomenon, for which they argue that a founder effect in Italian pedigrees with HT may explain this occurrence [39].

$M P L-\mathrm{K} 39 \mathrm{~N}$ is a polymorphism restricted to African Americans, and approximately $7 \%$ of African Americans are heterozygous for this mutation [40]. In contrast, MPL-P106L was found in approximately 6\% of Arabic individuals but not in Caucasian individuals [41]. These observations may indicate ethnic specificity for these two mutations. Both of these mutations are located within the extracellular domain of CD110, which may affect TPO binding, thereby leading to the defective clearance of TPO and thus causing thrombocythaemia. However, whether the two mutations correlate with complications, such as thrombosis or bleeding, requires additional statistical analysis of the data.

\section{MPL-W515L/K associated with MPNs, RARS-t and AML}

The two mutations were independently assessed because the most recent $2008 \mathrm{WHO}$ diagnostic criteria for MPNs highlights the function of the $M P L-W 515 \mathrm{~L} / \mathrm{K}$ mutations in the diagnosis of ET and PMF [42]. This was the first time that these mutations appeared in the diagnostic criteria.

Although JAK2V617F is the most common mutation in BCR-ABL-negative MPNs, approximately $50 \%$ of ET and PMF patients are JAK2V617F-negative [43-47]. In 2006, $M P L-W 515 \mathrm{~L}$ was identified by Pikman et al., and $M P L-$ W515K was discovered several months later $[48,49]$. The frequency rates of $M P L-W 515 \mathrm{~L} / \mathrm{K}$ in ET and PMF patients are approximately $1 \%$ and $5 \%$, respectively, but they are rarely found in PV patients [48,50]. Interestingly, the proportion of the MPL-W515L mutations is higher than that of $M P L-W 515 \mathrm{~K}$ mutations in MPN patients, although the ratio of homozygous patients is lower for the $M P L$ W515L mutation [51-53]. These mutations were identified not only in granulocytes but also in monocytes, B cells, $\mathrm{T}$ cells, NK cells, and even haematopoietic stem cells [54-56]. However, increased mutation levels in the myeloid lineage combined with the observation that MPN is a myeloproliferative rather than a lymphoproliferative disorder suggest a proliferative advantage toward the myeloid series induced by MPL-W515 mutations [54].

The following aspects clearly indicate the close relationship between $M P L-W 515 \mathrm{~L} / \mathrm{K}$ mutations and the pathogenesis of MPNs. 1. MPL-W515L/K mutations are located in the unique amphipathic KWQFP motif of CD110, which is important for preventing its spontaneous activation [5]. Thus, MPL-W515L/K mutations may cause spontaneous activation. In in vitro assays, several signalling pathways were constitutively phosphorylated and the $\mathrm{S}$ phase of the cell cycle was enhanced in $M P L$-W515L/K-expressing cell lines; even when deprived of cytokines, cytokine-independent colony formation and higher megakaryocytic cloning efficiency have been reported $[49,57]$. In this process, the cytosolic tyrosine 112 of CD110 MPL-W515 mutants is crucial and represents a potential target for pharmacologic inhibition [58]. 2. In in vivo assays, the analysis of tumourigenesis induction capacity of $M P L-W 515 \mathrm{~L} / \mathrm{K}$ mutants in nude mice revealed a clinical phenomenon similar to that observed with ET and PMF and showed atypical megakaryocytic hyperplasia, splenomegaly and thrombocytosis $[49,57,59]$. 
3. Currently, MPL-W515L/K mutations have not been observed in normal individuals, and several studies have indicated that MPN patients with MPL-W515L/K mutations present with older age, lower haemoglobin levels and higher platelet counts. However, the relationship between mutation and complications, such as thrombosis, remains unclear $[51,53,60]$. 4. Two MPL-W515L mutation-positive PMF patients were treated with allogeneic stem cell transplantation (allo)-SCT, and the MPL-W515L mutation was not detected after allo-SCT and mutation status remained negative for a long follow-up period, which is in line with the absence of clinical or molecular relapse [61]. This observation suggests that the MPL-W515L mutation could be used as a minimal residual disease marker and shows that $M P L-W 515 L$ plays a pathogenic role in MPN. 5. As mentioned above, $M P L-\mathrm{W} 515 \mathrm{~L} / \mathrm{K}$ mutations may cause spontaneous signal transduction, including that of the JAKSTAT/Crkl pathway. Moreover, various small molecule JAK kinase inhibitors not only inhibit spontaneous activation, thereby reducing the colony-forming capacity of cells with $M P L-W 515 \mathrm{~L} / \mathrm{K}$ mutation in in vitro assays, but also effectively relieve the symptoms observed in a MPL-W515L murine model of MPN [59,62]. Additionally, JAK kinase inhibitors display therapeutic value for MPN patients with $M P L-W 515 \mathrm{~L} / \mathrm{K}$ mutations [63-65]. These observations confirm the status of $M P L-W 515 \mathrm{~L} / \mathrm{K}$ in MPNs.

The MPL-W515L mutation has also been identified in RARS-t and AML patient samples. Currently, RARS-t patients harbouring the MPL-W515L mutation are rare [66-68]. However, the mutation rate of $M P L-W 515 \mathrm{~L}$ has been found to be as high as $25 \%$ in acute megakaryoblastic leukaemia (AMKL) with myelofibrosis, which is a subtype of AML [69]. The MPL-W515L mutation may also be involved in the pathogenesis of RARS-t and AML; however, as reports on this topic are sparse, the function of the mutation in these two diseases remains uncertain.

\section{Other MPL mutations}

Due to the extremely low mutation rate and unknown function of some mutations, we classified these mutations together into one group. Compared with the $M P L-$ W515L/K mutations, MPL-W515A/R mutations were found to be significantly less frequent $[48,52,57]$. However, it is conceivable that $M P L-W 515 \mathrm{~A} / \mathrm{R}$ mutations function via a mechanism similar to that of the $M P L$ W515L/K mutations, as they are mutations of the same

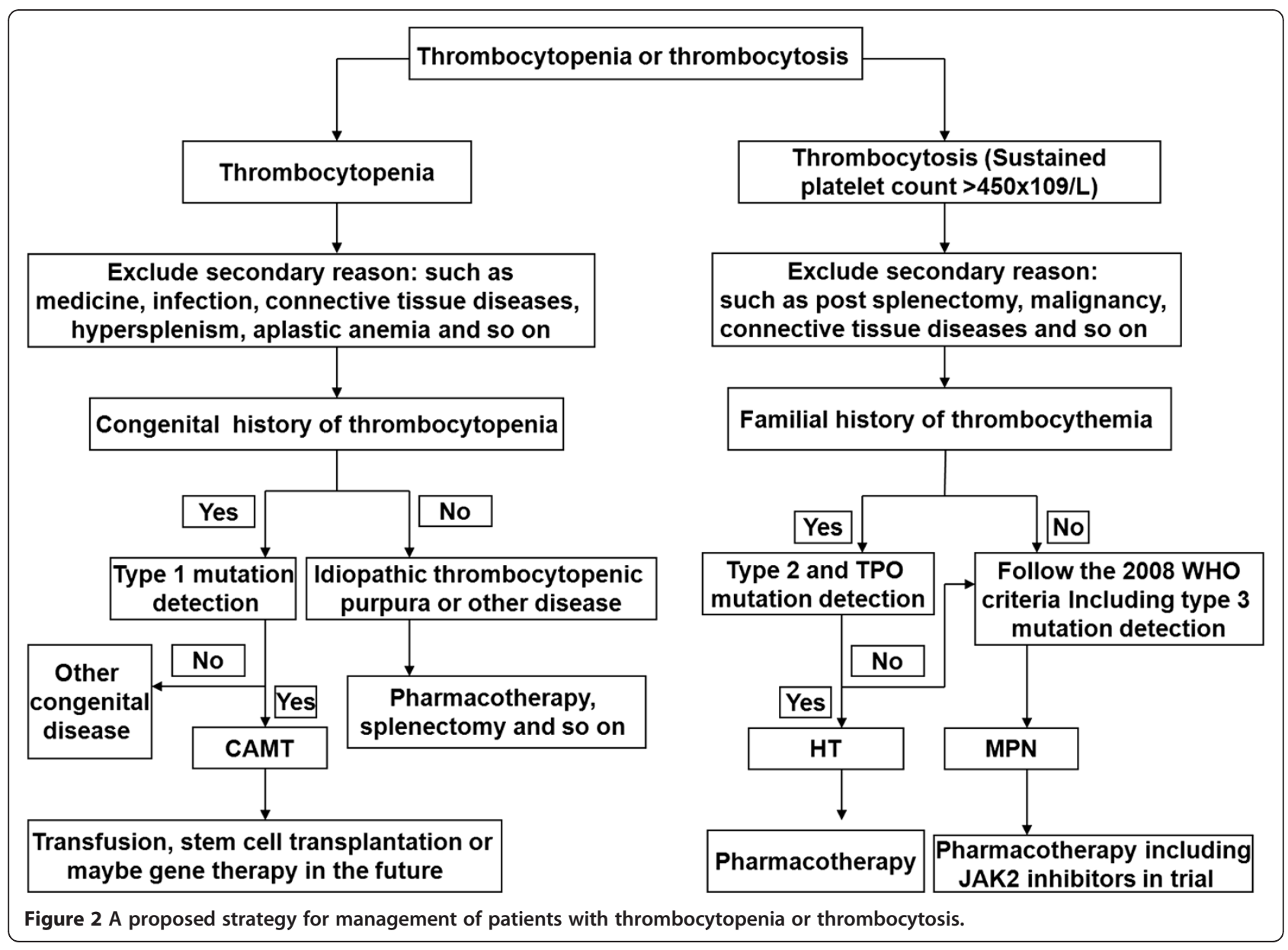


amino acid. MPL-A519T, L510P and A506T mutations are not gain-of-function mutations, and some scholars have hypothesised that these mutations have no relevance to haematological disease or may be regulators of other genetic events [57]. In contrast to other mutations, $M P L-T 487 \mathrm{~A}$ was observed in an acute megakaryoblastic leukaemia (AMKL) patient and induces a myeloproliferative disorder in mice by conferring the ability of cytokine-independent cell growth [70]. The recently detected $M P L-\mathrm{Y} 252 \mathrm{H}$ mutation in ET also displays a growth-promoting effect [71]. However, the function of the MPL-Y591D, W515-P518delinsKT, S204P/F, IVS 11/12 and IVS 10/11 mutations remains unknown [72-74].

\section{Conclusions}

In conclusion, several MPL mutations have been identified in association with haematopoietic diseases. These mutations may alter the normal regulatory mechanisms and lead to autonomous activation or signal deficiency. In this review, we assessed 59 different MPL mutations and classified these mutations into four different groups based on the associated diseases and mutation rates. Using this classification, we clearly demonstrate the existence of four diverse types of $M P L$ mutations and their clinical significance. Different types of $M P L$ mutations induce distinct haematopoietic diseases, and the same haematopoietic diseases may be caused by different mutations. Therefore, individual treatment regimens are required to intervene in haematopoietic disease based on the type of mutation present. We proposed a strategy for patients with thrombocytopenia or thrombocytosis, especially with a family history and congenital history (Summarised in Figure 2). For example, for patients with thrombocytopenia, excluding secondary causes (i.e., medicine, infection, connective tissue diseases, hypersplenism or aplastic anaemia), a screening for Type 1 MPL mutations should be performed, especially for patients with a congenital history. If a Type 1 mutation is present, a diagnosis of congenital amegakaryocytic thrombocytopenia can be suggested and an appropriate therapeutic schedule can be formulated, including transfusion, stem cell transplantation or even gene therapy in the future. Otherwise, other congenital diseases should be considered. For patients without a congenital history, primary and exclusive diseases may be considered, such as idiopathic thrombocytopenia purpura or other diseases, and pharmacotherapy, splenectomy and other therapies should be evaluated. When encountering patients with thrombocytosis (Sustained platelet count $>450 \times 10^{9} / \mathrm{L}$ ), excluding secondary reasons such as postsplenectomy, malignancy, and connective tissue diseases, Type 2 and TPO mutation screenings should be performed if the patients have familial history. If the patients test negative, a Type 3 mutation screening should be carried out. When patients test positive for Type 2 and TPO mutations, an HT diagnosis should be considered. However, when patients test negative for Type 2 and TPO mutations, sporadic thrombocythaemia should be considered while adhering to the 2008 WHO criteria [42]. Perhaps in the near future, when a diagnosis of MPN according to the $2008 \mathrm{WHO}$ criteria is possible, JAK2 inhibitors that are currently being assessed in trials may be available for patients.

Nevertheless, several questions regarding $M P L$ mutations remain unresolved. Why does one mutation, such as $M P L-W 515 \mathrm{~L}$, give rise to several disease phenotypes, namely ET, PMF, RARS-T and AML? The MPL-S505N mutation found in HT samples is a germline mutation; however, three acquired mutation cases were recently reported for MPNs [53,57]. Is this a coincidental phenomenon, and do other MPL mutations also possess this property? Finally, do JAK kinase inhibitors also have therapeutic potential for patients with $M P L$ mutations, such as MPL-S505N, that also cause signal activation?

\section{Abbreviations}

MPL: Human c-mpl gene; CAMT: Congenital amegakaryocytic thrombocytopenia; HT: Hereditary thrombocythaemia; MPNs: Myeloproliferative neoplasms; ET: Essential thrombocythaemia; PMF: Primary myelofibrosis; PV: Polycythaemia vera; AMKL: Acute megakaryoblastic leukaemia; RARS-t: Refractory anaemia with ringed sideroblasts associated with marked thrombocytosis.

\section{Competing interest}

The authors declare that they have no conflict of interest relating to the publication of this manuscript.

\section{Authors' contributions}

YJ and XQ contributed to data preparation. XH, ZC and XZ were involved in concept design, data collection, and manuscript preparation. All authors read and approved the final manuscript.

\section{Acknowledgments}

This work was supported by the Natural Science Foundation of Zhejiang province, China (Grant No. 2009c03012-4).

\section{Author details}

${ }^{1}$ Department of Hematology, the Second Affiliated Hospital, Zhejiang University School of Medicine, Hangzhou 310009, China. ${ }^{2}$ Department of Oncology, the Second Affiliated Hospital, Zhejiang University School of Medicine, Hangzhou 310009, China. ${ }^{3}$ Ultrasonic Diagnosis Deparment, the Second Affiliated Hospital, Zhejiang University School of Medicine, Hangzhou 310009, China

Received: 25 November 2012 Accepted: 22 January 2013

Published: 25 January 2013

\section{References}

1. Souyri M, Vigon I, Penciolelli JF, Heard JM, Tambourin P, Wendling F: A putative truncated cytokine receptor gene transduced by the myeloproliferative leukemia virus immortalizes hematopoietic progenitors. Cell 1990, 63:1137-1147.

2. Vigon I, Mornon JP, Cocault L, Mitjavila MT, Tambourin P, Gisselbrecht S, Souyri M: Molecular cloning and characterization of MPL, the human homolog of the v-mpl oncogene: identification of a member of the hematopoietic growth factor receptor superfamily. Proc Natl Acad Sci U S A 1992, 89:5640-5644. 
3. Mignotte V, Vigon I, de Crevecoeur EB, Romeo PH, Lemarchandel V, Chretien S: Structure and transcription of the human c-mpl gene (MPL). Genomics 1994, 20:5-12.

4. Sabath DF, Kaushansky K, Broudy VC: Deletion of the extracellular membranedistal cytokine receptor homology module of $\mathrm{Mpl}$ results in constitutive cell growth and loss of thrombopoietin binding. Blood 1999, 94:365-367.

5. Staerk J, Lacout C, Sato T, Smith SO, Vainchenker W, Constantinescu SN: An amphipathic motif at the transmembrane-cytoplasmic junction prevents autonomous activation of the thrombopoietin receptor. Blood 2006, 107:1864-1871.

6. Matthews EE, Thevenin D, Rogers JM, Gotow L, Lira PD, Reiter LA, Brissette WH, Engelman DM: Thrombopoietin receptor activation: transmembrane helix dimerization, rotation, and allosteric modulation. FASEB J 2011, 25:2234-2244.

7. Drachman JG, Kaushansky K: Dissecting the thrombopoietin receptor: functional elements of the Mpl cytoplasmic domain. Proc Natl Acad Sci U S A 1997, 94:2350-2355.

8. Sattler M, Durstin MA, Frank DA, Okuda K, Kaushansky K, Salgia R, Griffin JD: The thrombopoietin receptor c-MPL activates JAK2 and TYK2 tyrosine kinases. Exp Hemato/ 1995, 23:1040-1048.

9. Pallard C, Gouilleux F, Benit L, Cocault L, Souyri M, Levy D, Groner B, Gisselbrecht S, Dusanter-Fourt I: Thrombopoietin activates a STAT5-like factor in hematopoietic cells. EMBO J 1995, 14:2847-2856.

10. Miyakawa Y, Oda A, Druker BJ, Miyazaki H, Handa M, Ohashi H, Ikeda Y: Thrombopoietin induces tyrosine phosphorylation of Stat3 and Stat5 in human blood platelets. Blood 1996, 87:439-446

11. Sattler M, Salgia R, Durstin MA, Prasad KV, Griffin JD: Thrombopoietin induces activation of the phosphatidylinositol-3/ kinase pathway and formation of a complex containing p85PI3K and the protooncoprotein p120CBL. J Cell Physiol 1997, 171:28-33.

12. Ritchie A, Braun SE, He J, Broxmeyer HE: Thrombopoietin-induced conformational change in p53 lies downstream of the p44/p42 mitogen activated protein kinase cascade in the human growth factor-dependent cell line M07e. Oncogene 1999, 18:1465-1477.

13. Miyakawa Y, Rojnuckarin P, Habib T, Kaushansky K: Thrombopoietin induces phosphoinositol 3-kinase activation through SHP2, Gab, and insulin receptor substrate proteins in BAF3 cells and primary murine megakaryocytes. J Biol Chem 2001, 276:2494-2502.

14. Rouyez MC, Boucheron C, Gisselbrecht S, Dusanter-Fourt I, Porteu F: Control of thrombopoietin-induced megakaryocytic differentiation by the mitogen-activated protein kinase pathway. Mol Cell Biol 1997, 17:4991-5000

15. Rojnuckarin P, Drachman JG, Kaushansky K: Thrombopoietin-induced activation of the mitogen-activated protein kinase (MAPK) pathway in normal megakaryocytes: role in endomitosis. Blood 1999, 94:1273-1282.

16. Alexander WS, Maurer AB, Novak U, Harrison-Smith M: Tyrosine-599 of the c-Mpl receptor is required for Shc phosphorylation and the induction of cellular differentiation. EMBO J 1996, 15:6531-6540.

17. Hong Y, Dumenil D, van der Loo B, Goncalves F, Vainchenker W, Erusalimsky JD: Protein kinase $C$ mediates the mitogenic action of thrombopoietin in c-Mpl-expressing UT-7 cells. Blood 1998, 91:813-822.

18. Kunitama M, Shimizu R, Yamada M, Kato T, Miyazaki H, Okada K, Miura Y, Komatsu N: Protein kinase C and c-myc gene activation pathways in thrombopoietin signal transduction. Biochem Biophys Res Commun 1997, 231:290-294.

19. Miyakawa Y, Oda A, Druker BJ, Kato T, Miyazaki H, Handa M, Ikeda Y: Recombinant thrombopoietin induces rapid protein tyrosine phosphorylation of Janus kinase 2 and Shc in human blood platelets. Blood 1995, 86:23-27.

20. de Sauvage FJ, Hass PE, Spencer SD, Malloy BE, Gurney AL, Spencer SA Darbonne WC, Henzel WJ, Wong SC, Kuang WJ, et al: Stimulation of megakaryocytopoiesis and thrombopoiesis by the c-Mpl ligand. Nature 1994, 369:533-538.

21. Kaushansky K, Lok S, Holly RD, Broudy VC, Lin N, Bailey MC, Forstrom JW Buddle MM, Oort PJ, Hagen FS, et al: Promotion of megakaryocyte progenitor expansion and differentiation by the c-Mpl ligand thrombopoietin. Nature 1994, 369:568-571.

22. Ding J, Komatsu H, Wakita A, Kato-Uranishi M, Ito M, Satoh A, Tsuboi K, Nitta M, Miyazaki $H$, lida $S$, et al: Familial essential thrombocythemia associated with a dominant-positive activating mutation of the c-MPL gene, which encodes for the receptor for thrombopoietin. Blood 2004, 103:4198-4200.
23. Martinon-Torres N, Vazquez-Donsion M, Loidi L, Couselo JM: CAMT in a female with developmental delay, facial malformations and central nervous system anomalies. Pediatr Blood Cancer 2011, 56:452-453.

24. Teofili L, Giona F, Torti L, Cenci T, Ricerca BM, Rumi C, Nunes V, Foa R, Leone $G$, Martini $M$, et al: Hereditary thrombocytosis caused by MPLSer505Asn is associated with a high thrombotic risk, splenomegaly and progression to bone marrow fibrosis. Haematologica 2010, 95:65-70

25. Ballmaier M, Germeshausen M: Congenital amegakaryocytic thrombocytopenia: clinical presentation, diagnosis, and treatment. Semin Thromb Hemost 2011, 37:673-681.

26. Ballmaier M, Germeshausen M, Schulze H, Cherkaoui K, Lang S, Gaudig A Krukemeier S, Eilers M, Strauss G, Welte K: c-mpl mutations are the cause of congenital amegakaryocytic thrombocytopenia. Blood 2001, 97:139-146.

27. King S, Germeshausen M, Strauss G, Welte K, Ballmaier M: Congenital amegakaryocytic thrombocytopenia: a retrospective clinical analysis of 20 patients. Br J Haematol 2005, 131:636-644.

28. Germeshausen M, Ballmaier M, Welte K: MPL mutations in 23 patients suffering from congenital amegakaryocytic thrombocytopenia: the type of mutation predicts the course of the disease. Hum Mutat 2006, 27:296.

29. Tijssen MR, di Summa F, van den Oudenrijn S, Zwaginga JJ, van der Schoot CE, Voermans $C$, de Haas M: Functional analysis of single amino-acid mutations in the thrombopoietin-receptor Mpl underlying congenital amegakaryocytic thrombocytopenia. Br J Haematol 2008, 141:808-813.

30. Gandhi MJ, Pendergrass TW, Cummings CC, Ihara K, Blau CA, Drachman JG Congenital amegakaryocytic thrombocytopenia in three siblings: molecular analysis of atypical clinical presentation. Exp Hematol 2005, 33:1215-1221.

31. Rose MJ, Nicol KK, Skeens MA, Gross TG, Kerlin BA: Congenital amegakaryocytic thrombocytopenia: the diagnostic importance of combining pathology with molecular genetics. Pediatr Blood Cancer 2008, 50:1263-1265

32. Steinberg O, Gilad G, Dgany O, Krasnov T, Zoldan M, Laor R, Kapelushnik J, Gabriel H, Churi C, Stein J, et al: Congenital amegakaryocytic thrombocytopenia-3 novel c-MPL mutations and their phenotypic correlations. J Pediatr Hematol Oncol 2007, 29:822-825.

33. Ihara $K$, Ishii E, Equchi M, Takada H, Suminoe A, Good RA, Hara T: Identification of mutations in the c-mpl gene in congenital amegakaryocytic thrombocytopenia. Proc Natl Acad Sci U S A 1999, 96:3132-3136

34. Ding J, Komatsu H, lida S, Yano H, Kusumoto S, Inagaki A, Mori F, Ri M, Ito A, Wakita A, et al: The Asn505 mutation of the c-MPL gene, which causes familial essential thrombocythemia, induces autonomous homodimerization of the c-Mpl protein due to strong amino acid polarity. Blood 2009, 114:3325-3328.

35. Lee TS, Kantarjian H, Ma W, Yeh CH, Giles F, Albitar M: Effects of clinically relevant MPL mutations in the transmembrane domain revealed at the atomic level through computational modeling. PLoS One 2011, 6:e23396.

36. Teofili L, Giona F, Martini M, Cenci T, Guidi F, Torti L, Palumbo G, Amendola A, Foa R, Larocca LM: Markers of myeloproliferative diseases in childhood polycythemia vera and essential thrombocythemia. J Clin Oncol 2007, 25:1048-1053.

37. Teofili L, Giona F, Martini M, Cenci T, Guidi F, Torti L, Palumbo G, Amendola A, Leone G, Foa R, et al: The revised WHO diagnostic criteria for Ph-negative myeloproliferative diseases are not appropriate for the diagnostic screening of childhood polycythemia vera and essential thrombocythemia. Blood 2007, 110:3384-3386.

38. Teofili L, Foa R, Giona F, Larocca LM: Childhood polycythemia vera and essential thrombocythemia: does their pathogenesis overlap with that of adult patients? Haematologica 2008, 93:169-172

39. Liu K, Martini M, Rocca B, Amos Cl, Teofili L, Giona F, Ding J, Komatsu H, Larocca LM, Skoda RC: Evidence for a founder effect of the MPL-S505N mutation in eight Italian pedigrees with hereditary thrombocythemia. Haematologica 2009, 94:1368-1374.

40. Moliterno AR, Williams DM, Gutierrez-Alamillo LI, Salvatori R, Ingersoll RG, Spivak JL: Mpl Baltimore: a thrombopoietin receptor polymorphism associated with thrombocytosis. Proc Natl Acad Sci U S A 2004, 101:11444-11447.

41. El-Harith el HA, Roesl C, Ballmaier M, Germeshausen M, Frye-Boukhriss $H_{\text {, }}$ von Neuhoff N, Becker C, Nurnberg G, Nurnberg P, Ahmed MA, et al: Familial thrombocytosis caused by the novel germ-line mutation $\mathrm{p}$. Pro106Leu in the MPL gene. Br J Haematol 2009, 144:185-194. 
42. Tefferi A, Vardiman JW: Classification and diagnosis of myeloproliferative neoplasms: the 2008 World Health Organization criteria and point-ofcare diagnostic algorithms. Leukemia 2008, 22:14-22.

43. Levine RL, Wadleigh M, Cools J, Ebert BL, Wernig G, Huntly BJ, Boggon TJ, Wlodarska I, Clark JJ, Moore S, et al: Activating mutation in the tyrosine kinase JAK2 in polycythemia vera, essential thrombocythemia, and myeloid metaplasia with myelofibrosis. Cancer Cell 2005, 7:387-397.

44. Kralovics R, Passamonti F, Buser AS, Teo SS, Tiedt R, Passweg JR, Tichelli A, Cazzola M, Skoda RC: A gain-of-function mutation of JAK2 in myeloproliferative disorders. N Engl J Med 2005, 352:1779-1790.

45. Zhao W, Gao R, Lee J, Xing S, Ho WT, Fu X, Li S, Zhao ZJ: Relevance of JAK2V617F positivity to hematological diseases-survey of samples from a clinical genetics laboratory. J Hematol Oncol 2011, 4:4.

46. Zhao AH, Gao R, Zhao ZJ: Development of a highly sensitive method for detection of JAK2V617F. J Hematol Oncol 2011, 4:40.

47. Zhao W, Du Y, Ho WT, Fu X, Zhao ZJ: JAK2V617F and p53 mutations coexist in erythroleukemia and megakaryoblastic leukemic cell lines. Exp Hematol Oncol 2012, 1:15

48. Pardanani $A D$, Levine $R L$, Lasho $T$, Pikman $Y$, Mesa RA, Wadleigh $M$, Steensma DP, Elliott MA, Wolanskyj AP, Hogan WJ, et al: MPL515 mutations in myeloproliferative and other myeloid disorders: a study of 1182 patients. Blood 2006, 108:3472-3476.

49. Pikman Y, Lee BH, Mercher T, McDowell E, Ebert BL, Gozo M, Cuker A, Wernig G, Moore S, Galinsky l, et al: MPLW515L is a novel somatic activating mutation in myelofibrosis with myeloid metaplasia. PLOS Med 2006, 3:e270.

50. Pardanani A, Lasho TL, Finke CM, Tefferi A: Infrequent occurrence of MPL exon 10 mutations in polycythemia vera and post-polycythemia vera myelofibrosis. Am J Hematol 2011, 86:701-702.

51. Vannucchi AM, Antonioli E, Guglielmelli P, Pancrazzi A, Guerini V, Barosi G, Ruggeri M, Specchia G, Lo-Coco F, Delaini F, et al: Characteristics and clinical correlates of MPL 515W>L/K mutation in essential thrombocythemia. Blood 2008, 112:844-847.

52. Schnittger S, Bacher U, Haferlach C, Beelen D, Bojko P, Burkle D, Dengler R, Distelrath A, Eckart M, Eckert R, et al: Characterization of 35 new cases with four different MPLW515 mutations and essential thrombocytosis or primary myelofibrosis. Haematologica 2009, 94:141-144.

53. Beer PA, Campbell PJ, Scott LM, Bench AJ, Erber WN, Bareford D, Wilkins BS, Reilly JT, Hasselbalch HC, Bowman R, et al: MPL mutations in myeloproliferative disorders: analysis of the PT-1 cohort. Blood 2008, 112:141-149.

54. Chaligne $\mathrm{R}$, James C, Tonetti C, Besancenot R, Le Couedic JP, Fava F, Mazurier F, Godin I, Maloum K, Larbret F, et al: Evidence for MPL W515L/K mutations in hematopoietic stem cells in primitive myelofibrosis. Blood 2007, 110:3735-3743.

55. Pardanani A, Lasho TL, Finke C, Markovic SN, Tefferi A: Demonstration of MPLW515K, but not JAK2V617F, in in vitro expanded CD4+ T lymphocytes. Leukemia 2007, 21:2206-2207.

56. Hu WY, Zhao Y, Ishii T, Sozer S, Shi J, Zhang W, Bruno E, Hoffman R, Xu M: Haematopoietic cell lineage distribution of MPLW515L/K mutations in patients with idiopathic myelofibrosis. Br J Haematol 2007, 137:378-379.

57. Chaligne R, Tonetti C, Besancenot R, Roy L, Marty C, Mossuz P, Kiladjian JJ, Socie G, Bordessoule D, Le Bousse-Kerdiles MC, et al: New mutations of MPL in primitive myelofibrosis: only the MPL W515 mutations promote a G1/S-phase transition. Leukemia 2008, 22:1557-1566.

58. Pecquet C, Staerk J, Chaligne R, Goss V, Lee KA, Zhang X, Rush J, Van Hees J, Poirel HA, Scheiff JM, et al: Induction of myeloproliferative disorder and myelofibrosis by thrombopoietin receptor W515 mutants is mediated by cytosolic tyrosine 112 of the receptor. Blood 2010, 115:1037-1048.

59. Wernig G, Kharas MG, Mullally A, Leeman DS, Okabe R, George T, Clary DO, Gilliland DG: EXEL-8232, a small-molecule JAK2 inhibitor, effectively treats thrombocytosis and extramedullary hematopoiesis in a murine model of myeloproliferative neoplasm induced by MPLW515L. Leukemia 2012, 26:720-727.

60. Guglielmelli P, Pancrazzi A, Bergamaschi G, Rosti V, Villani L, Antonioli E, Bosi A, Barosi G, Vannucchi AM: Anaemia characterises patients with myelofibrosis harbouring Mpl mutation. Br J Haematol 2007, 137:244-247.

61. Alchalby $H$, Badbaran A, Bock O, Fehse B, Bacher U, Zander AR, Kroger N: Screening and monitoring of MPL W515L mutation with real-time PCR in patients with myelofibrosis undergoing allogeneic-SCT. Bone Marrow Transplant 2010, 45:1404-1407.
62. Pardanani A, Hood J, Lasho T, Levine RL, Martin MB, Noronha G, Finke C, Mak CC, Mesa R, Zhu H, et al: TG101209, a small molecule JAK2-selective kinase inhibitor potently inhibits myeloproliferative disorder-associated JAK2V617F and MPLW515L/K mutations. Leukemia 2007, 21:1658-1668.

63. Verstovsek S, Kantarjian H, Mesa RA, Pardanani AD, Cortes-Franco J, Thomas DA, Estrov Z, Fridman JS, Bradley EC, Erickson-Viitanen S, et al: Safety and efficacy of INCB018424, a JAK1 and JAK2 inhibitor, in myelofibrosis. N Engl J Med 2010, 363:1117-1127.

64. Pardanani A, Gotlib JR, Jamieson C, Cortes JE, Talpaz M, Stone RM, Silverman MH, Gilliland DG, Shorr J, Tefferi A: Safety and efficacy of TG101348, a selective JAK2 inhibitor, in myelofibrosis. J Clin Oncol 2011, 29:789-796.

65. MN Furqan M, Lee B, Liu D: Dysregulation of JAK-STAT pathway in hematological malignancies and JAK inhibitors for clinical application. Biomarker Research 2013, 1:5.

66. Szpurka H, Gondek LP, Mohan SR, Hsi ED, Theil KS, Maciejewski JP: UPD1p indicates the presence of MPL W515L mutation in RARS-T, a mechanism analogous to UPD9p and JAK2 V617F mutation. Leukemia 2009, 23:610-614.

67. Schnittger S, Bacher U, Haferlach C, Dengler R, Krober A, Kern W, Haferlach T: Detection of an MPLW515 mutation in a case with features of both essential thrombocythemia and refractory anemia with ringed sideroblasts and thrombocytosis. Leukemia 2008, 22:453-455.

68. Schmitt-Graeff AH, Teo SS, Olschewski M, Schaub F, Haxelmans S, Kirn A, Reinecke P, Germing U, Skoda RC: JAK2V617F mutation status identifies subtypes of refractory anemia with ringed sideroblasts associated with marked thrombocytosis. Haematologica 2008, 93:34-40.

69. Hussein K, Bock O, Theophile K, Schulz-Bischof K, Porwit A, Schlue J, Jonigk D, Kreipe H: MPLW515L mutation in acute megakaryoblastic leukaemia. Leukemia 2009, 23:852-855.

70. Malinge S, Ragu C, Della-Valle V, Pisani D, Constantinescu SN, Perez C, Villeval JL, Reinhardt D, Landman-Parker J, Michaux L, et al: Activating mutations in human acute megakaryoblastic leukemia. Blood 2008, 112:4220-4226

71. Lambert MP, Jiang J, Batra V, Wu C, Tong W: A novel mutation in MPL $(\mathrm{Y} 252 \mathrm{H})$ results in increased thrombopoietin sensitivity in essential thrombocythemia. Am J Hematol 2012, 87:532-534.

72. Kawamata N, Ogawa S, Yamamoto G, Lehmann S, Levine RL, Pikman Y, Nannya Y, Sanada M, Miller CW, Gilliland DG, et al: Genetic profiling of myeloproliferative disorders by single-nucleotide polymorphism oligonucleotide microarray. Exp Hematol 2008, 36:1471-1479.

73. Williams DM, Kim AH, Rogers O, Spivak JL, Moliterno AR: Phenotypic variations and new mutations in JAK2 V617F-negative polycythemia vera, erythrocytosis, and idiopathic myelofibrosis. Exp Hematol 2007, 35:1641-1646.

74. Ohashi H, Arita K, Fukami S, Oguri K, Nagai H, Yokozawa T, Hotta T, Hanada S: Two rare MPL gene mutations in patients with essential thrombocythemia. Int J Hematol 2009, 90:431-432.

\section{doi:10.1186/1756-8722-6-11}

Cite this article as: He et al:: Different mutations of the human c-mpl gene indicate distinct haematopoietic diseases. Journal of Hematology \& Oncology 2013 6:11

\section{Submit your next manuscript to BioMed Central and take full advantage of:}

- Convenient online submission

- Thorough peer review

- No space constraints or color figure charges

- Immediate publication on acceptance

- Inclusion in PubMed, CAS, Scopus and Google Scholar

- Research which is freely available for redistribution 